\title{
An Emergy-Based Approach to Assess and Valuate Ecosystem Services of Tropical Wetland Pastures in Brazil
}

\section{Sandra Aparecida Santos ${ }^{1}$, Fábio Takahashi ${ }^{2}$, Evaldo Luís Cardoso ${ }^{1}$, Claudio Flores ${ }^{1}$, Luiz Orcírio Fialho de Oliveira ${ }^{3}$, Geraldo da Silva e Souza ${ }^{4}$, Eliane Gonçalves Gomes ${ }^{4}$, Enrique Ortega ${ }^{5}$}

\author{
${ }^{1}$ Embrapa Pantanal, Corumbá, MS, Brasil \\ ${ }^{2}$ Universidade de Viçosa, Florestal, MG, Brasil \\ ${ }^{3}$ Embrapa Gado de Corte, Campo Grande, MS, Brasil \\ ${ }^{4}$ Embrapa Sede, Brasília, DF, Brasil \\ ${ }^{5}$ Universidade de Campinas, Barão Geraldo, SP, Brasil \\ Email: *sandra.santos@embrapa.br
}

How to cite this paper: Santos, S.A., Takahashi, F., Cardoso, E.L., Flores, C., de Oliveira, L.O.F., da Silva e Souza, G., Gomes, E.G. and Ortega, E. (2020) An Emergy-Based Approach to Assess and Valuate Ecosystem Services of Tropical Wetland Pastures in Brazil. Open Journal of Ecology, 10, 303-319. https://doi.org/10.4236/oje.2020.105019

Received: April 17, 2020

Accepted: May 26, 2020

Published: May 29, 2020

Copyright $\odot 2020$ by author(s) and Scientific Research Publishing Inc. This work is licensed under the Creative Commons Attribution International License (CC BY 4.0).

http://creativecommons.org/licenses/by/4.0/

\begin{abstract}
Wetland grasslands are important ecosystems for raising beef cattle, because they are highly productive and present forages with high quality. Most of these ecosystems are threatened by overgrazing or by being replaced by exotic pastures. Emergy synthesis approach was used to assess and value the services provided by native pastures wetland under three conservation status and also to compare them to exotic pastures on wetlands. The ecosystem service that was assessed included forage provision for calves production estimated from grazing capacity of cow with calf at the foot. Habitat maintenance to plant diversity and wild herbivores were also evaluated. The results showed that natural wetland pastures with better conservation status provided valuable ecosystem services and are highly renewable. Data envelopment analysis (DEA) showed that regardless of the conservation state of the natural pastures, wet native grasslands were more efficient than wet exotic grasslands. Replacing native pastures by exotic ones may reduce plant diversity and the renewability of the system. The proposed method has a holistic approach to pasture ecosystems and is able to help decision-makers to define sustainable management practices and to subsidise public policies when it comes to payments regarding ecosystem services.
\end{abstract}

\section{Keywords}

Data Envelopment Analysis, Forage Resources, Natural Pasture, Plant Diversity, Sustainability 


\section{Introduction}

Wetlands are one of the world's most productive ecosystems, contributing with about $40 \%$ of the planet's ecosystem services such as biodiversity protection, water storage, flood control, groundwater replenishment, sediment and nutrient retention, wildlife habitats, carbon sink, climate regulation, cultural values, recreation and tourism and food for animals [1] [2] [3]. Ecosystem services are direct and indirect benefits of ecosystems for human well-being [4] [5]. Definitions and classifications of ecosystem services has sought separation between intermediate and final service to avoid risk of double counting [6], focusing on "final outputs" from ecosystems that people use and value [7].

Over $60 \%$ of the services provided by ecosystems have been degraded in the past 50 years [8]. Studies about quantification and valuation of the services are required for a better understanding of what the ecosystem services require and it is also necessary that these studies be used in decision making and for planning the sustainable use of these resources [7] [9]. Over the past decades, progress was observed in the researches with ecosystem services with the use of different methodologies [10] [11], including emergy analysis [12] [13] [14], which takes into account a systemic analysis and allows to evaluate the complex and multifunctional nature of the extensive livestock systems [15].

Brazilian Pantanal is considered to be the world's major floodplain comprising a forest-savanna-wetland complex mosaic of $147,574 \mathrm{~km}^{2}$, influenced by neighbouring biomes [16]. This mosaic landscape is hydrologically controlled and highly dynamic by wet-season flood pulse, which probably contributes to its low levels of endemism [17]. The diversity of forage resources makes the region suitable for beef cattle ranching in extensive systems, mainly beef calves' production. At present, about $95 \%$ of Pantanal is occupied by private farms of livestock [18], thus the sustainability of this activity depends on natural forage resources variable between the distinct sub-regions. The main vegetation types used for foraging are floodplain rangelands, especially open grasslands and edges of water bodies such [19]. Thus, wetlands which are dominated by grasses are heavily used for cattle grazing as the upland landscapes generally have a lower quality of pasture. In general, these areas are replaced by exotic grasses such as Urochloa humidicola, which produce more dry mass. However, this practice has been intensified in the region, thus having a negative impact when reaching wetland landscapes. The grasses Urochloa radicans and Panicum repens are invading the wetlands and therefore becoming a serious threat to the native biodiversity and ecosystem services. Efforts and conservation strategies are necessary in order to protect Pantanal wetlands from human impacts [18].

Considering that grazing wetlands have several benefits, mainly the provision of high quality forage to beef cow-calf production, which is a service with economic value, quantifying this service could be one of the strategies.

To deal with this challenge, the aim of this study was:

1) To assess native pasture wetland under different conservation status; 
2) To quantify the services of wetland with native pasture and converted to exotic pastures for weaned calves' production;

3) To suggest strategies to subsidy public policies in order to encourage ranchers to conserve native pasture wetland and ecosystem services.

\section{Material and Methods}

\subsection{Study Area and Sampling Methods}

The study area is located in the Nhecolândia sub-region $\left(18^{\circ} 59^{\prime} 11^{\prime \prime} \mathrm{S}\right.$ $56^{\circ} 37^{\prime} 19^{\prime \prime}$ ), Pantanal, in the State of Mato Grosso do Sul, Brazil. This region is characterised by a mosaic of vegetation physiognomies comprising the "cordilheiras" that are the highest parts of the mesorelief, generally covered with forested savannas or a semi-deciduous forest; savanna woodlands; open grasslands and small permanent and temporary ponds (depression locally known as "baías"). Ponds are considered wetlands and their dry edge varies according to the wet/dry cycle as well as the forage available, which is influenced by the pluvial flooding (Figure 1). In general, pond edges are covered by aquatic macrophytes, especially $\mathrm{C} 3$ grasses such as Hymenachne amplexicaulis and Luziola subintegra. This sub-region is suitable for livestock ranching [18]. The soils are of sandy texture classified as Hydromorphic Quartzarenic Neosoil (Entisol) [20].

Data were obtained from an experiment conducted during the hydrological year from October 2014 to September 2015, on natural grassland wetlands (pond edges) under three different conservation degrees: optimum, regular and marginal [21], with three repetitions distributed over eight management units (MU)
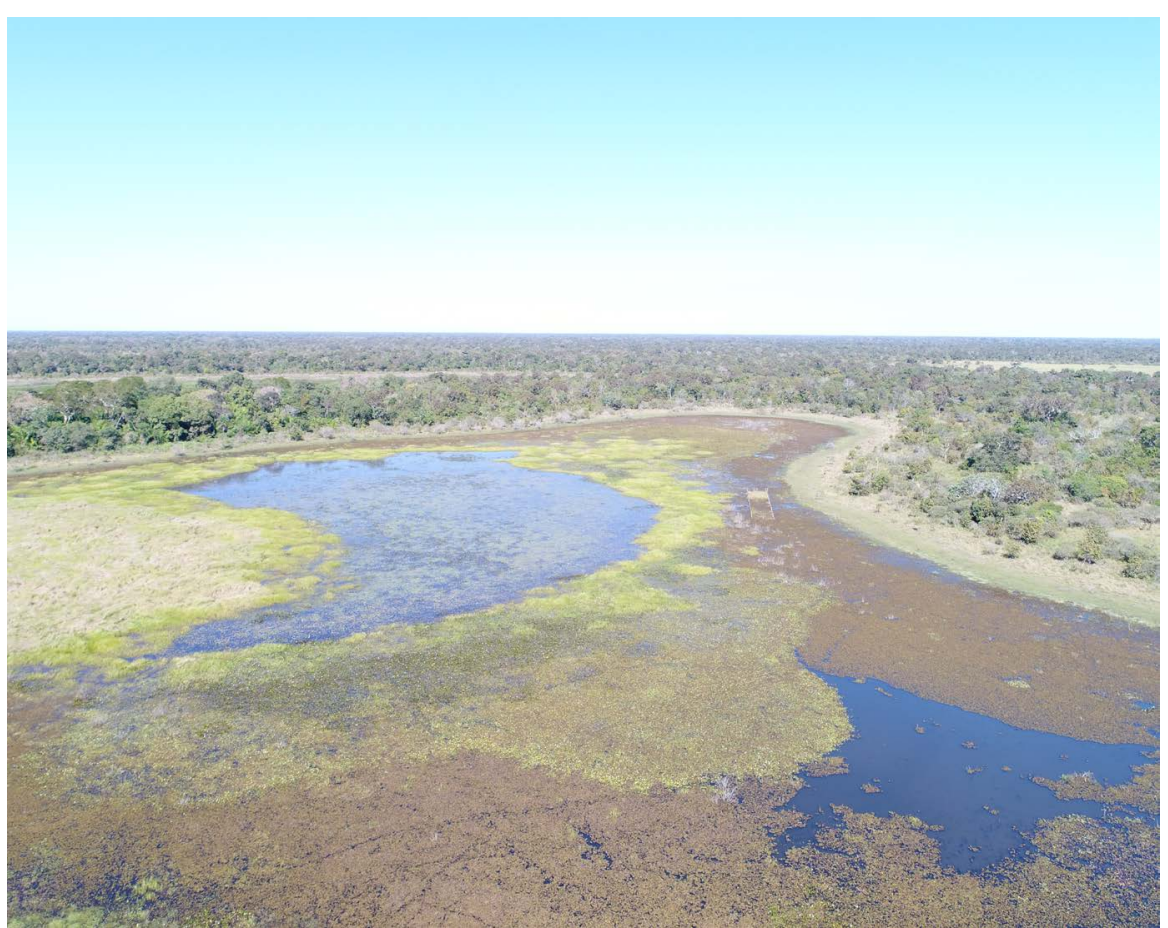

Figure 1. Native pasture wetland around the edge of a pond in the Nhecolândia sub-region, Brazilian Pantanal during wet season. 
located on the Nhumirim ranch, Embrapa Pantanal. A reference pond edge dominated by Urochloa humidicola was also evaluated, totalising nine pond edges. On nine of the pond edges, the historical management was beef cow-calf production with low stocking rate $\left(0.3 \mathrm{AU} \cdot \mathrm{ha}^{-1}\right)$ in a continuous grazing system (Figure 2). The total precipitation records for the hydrological year 2014/2015 were $1148.8 \mathrm{~mm}$ near climatological normal of 1139.8 ( 35 years average). The total precipitation during the rainy period (October to March) was within the average and the dry period (April to September) was slightly above the average in comparison to the climatological normal means (data collected at the climatological station of Nhumirim ranch).

In each pond, three grazing cages $\left(1 \mathrm{~m}^{2}\right)$ were allocated in order to estimate forage and no forage mass accumulation rates from September 2014 to March 2015, according to the triple pairing methodology [22]. Aboveground plants were clipped in $0.25 \mathrm{~m}^{2}$ plots inside and outside of the exclusion cage in October

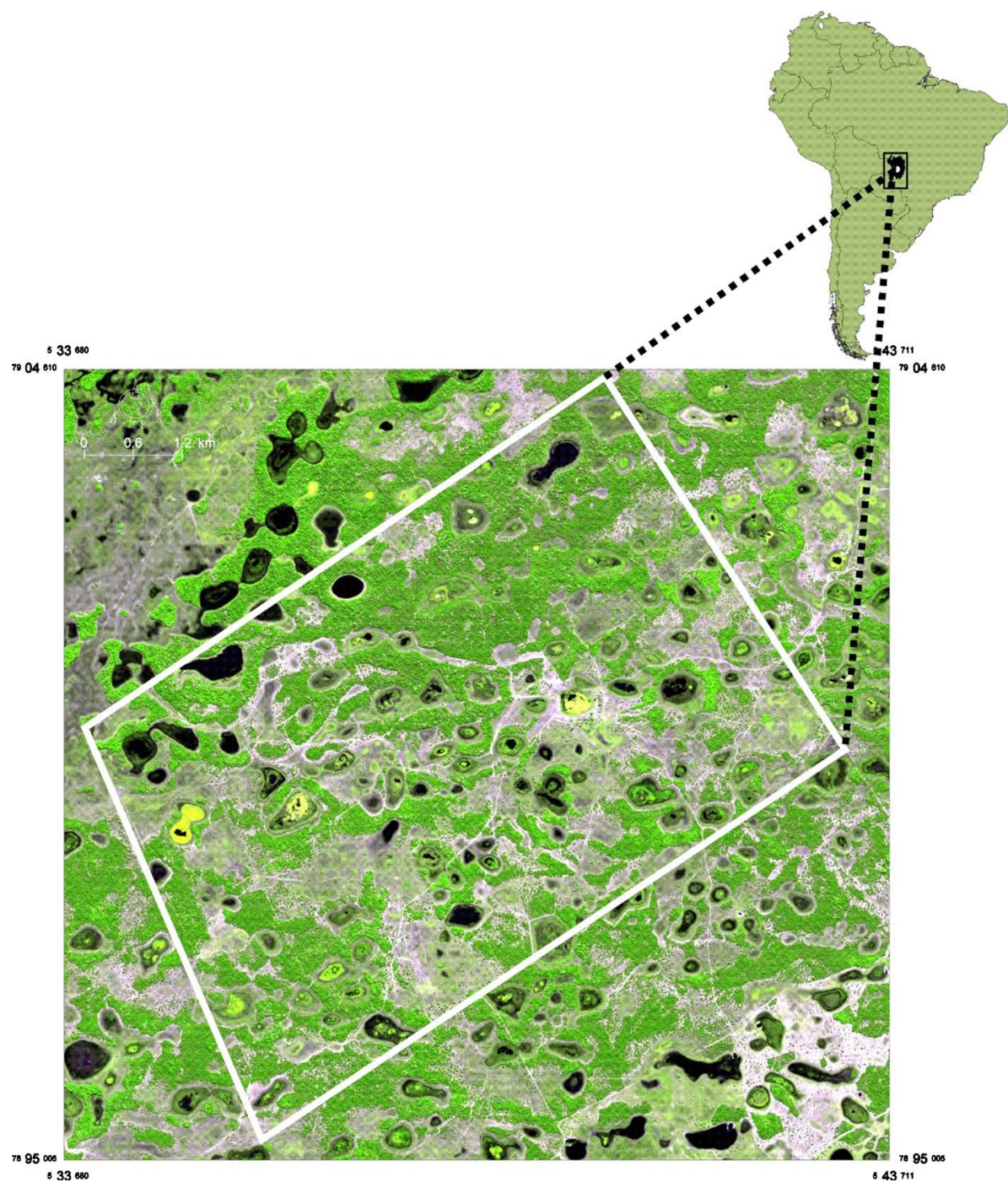

Figure 2. Map of the study area showing the mosaic of vegetation physiognomies with small permanent and temporary ponds on the Nhumirim ranch, Embrapa Pantanal, Brazil. 
2014 (late dry season) and April 2015 (late rainy season) and put in an oven at $65^{\circ} \mathrm{C}$ for three days for further analysis at the Laboratory of Chemical Analysis of the Embrapa Pantanal. Dry matter was analysed according to the AOAC with adaptations [23]. Root samples were collected in native wetland pastures in November 2014, using the monolith method that consists of the removal of soil blocks with roots. A cylindrical root collector $17 \mathrm{~cm}$ deep and $9 \mathrm{~cm}$ in diameter was used, with a volume of $0.00085 \mathrm{~m}^{3}$. The roots collected were washed in the laboratory with the use of a hose and sieves to separate them from the soil. The roots were then weighed and dried. As this layer up to $20 \mathrm{~cm}$ represents about $70 \%$ of the root system dry matter [24] thirty percent was added so as to estimate belowground dry matter. The net primary productivity (NPP) was estimated by summing the aerial and the root dry mass.

Two phases are followed in order to quantify the provision service offered by wetland pastures:

Phase 1. understanding and quantifying wetland pasture ecosystem services

It was assessed: forage provision for calves production and wild herbivores maintenance ( $\mathrm{t} \mathrm{DM} \mathrm{ha}{ }^{-1}$ ) and plant diversity. Weaned calves are the main product of the Pantanal. For each state of conservation of the pasture, the total usable forage as a product of the annual forage production, degree of utilisation and area ( $1 \mathrm{ha}$ ) were calculated. The degree of utilisation adopted was $50 \%$. The average annual forage production was based on key forages [25].

The calculation for the demand of forage was determined by the product of the body weight (measured as an animal unit), grazing time (365 days) and intake. In this study an animal unit (AU), a "pantaneira" cow of $350 \mathrm{~kg}$ and its calf equals about $450 \mathrm{~kg}$ [25], a capybara of $40 \mathrm{~kg}$, and a deer of $30 \mathrm{~kg}$ were considered. The intake was estimated as the percentage of the body weight of each animal. Two percent for cattle while for the wild herbivores four per cent were considered to assess the grazing capacity [26] [27]. The data of the grazing capacity of browser/grazer used in this research was obtained from the distribution of densities and metabolic biomass of medium- to large-sized nonvolant mammals in the forest, savanna and floodplain landscapes, in an area with low anthropogenic influence, in the central area of the Brazilian Pantanal, during a prolonged drought. The following browsers/graziers were considered: Hydrochaeris hydrochaeris, Mazama gouazoubira, Mazama Americana, Ozotoceros bezoarticus, Blastocerus dichotomus and Tapirus terrestris [28]. Livestock (cows with calf at the foot) and wildlife production was evaluated by using grazing capacity that is reflected by the animal production defined by $\mathrm{kg} \cdot \mathrm{ha}^{-1}$.

The diversity of plant and forage resources were evaluated by using the step point method along with a walking transect of 100 points at random on the pond's area [29]. Overall richness (number of plant species) and number of forage species were calculated for each pond and conservation status. The diversity of plants was quantified as a function of the Pantanal area (ha) and the number 
of existing plant species. One thousand ninety hundred plant species [30] were considered in an area of $150.355 \mathrm{~km}^{2}(15,035,500 \mathrm{ha})$.

\section{Phase 2. Emergy methodology approach}

For the evaluation of the wetland grassland ecosystems, the emergy methodology was used [13]. It consists in the conversion of the ecosystem goods and services expressed in solar emjoules (sej). This methodology presents advantages regarding the economic methods, since it values the true nature of the contribution. The emergy analysis consists of the following phases: 1- to define the boundary system through a diagram to characterise the system components, sources and emergy flows, describing the input/output (Figure 3). The diagram includes both economic and nature resources and shows all relevant interactions. Primary renewable flows are sunlight, rainfall and water table. After the definition of the diagram, a table of emergy flows was constructed, where numerical values and units were placed for each flow that allowed for the multiplication of all the components by their respective transformity in order to arrive at the emergy flow. The transformity for diversity of plants was calculated based on the renewable potential of the region considering the emergy flow of precipitation: $2.02 \times 1015 \mathrm{sej}\left(\right.$ ha.year $\left.{ }^{-1}\right)$. The relationship of this value multiplied by area and divided by the species number results in the value sej/species.

The countability of the data regarding optimum conservation status is presented in Appendix 1.

In order to assess the ecosystem services, the value of $1.18 \mathrm{E}+13 \mathrm{seJ} / \mathrm{USD}$ was considered, which refers to the relation between the emergy of the country and

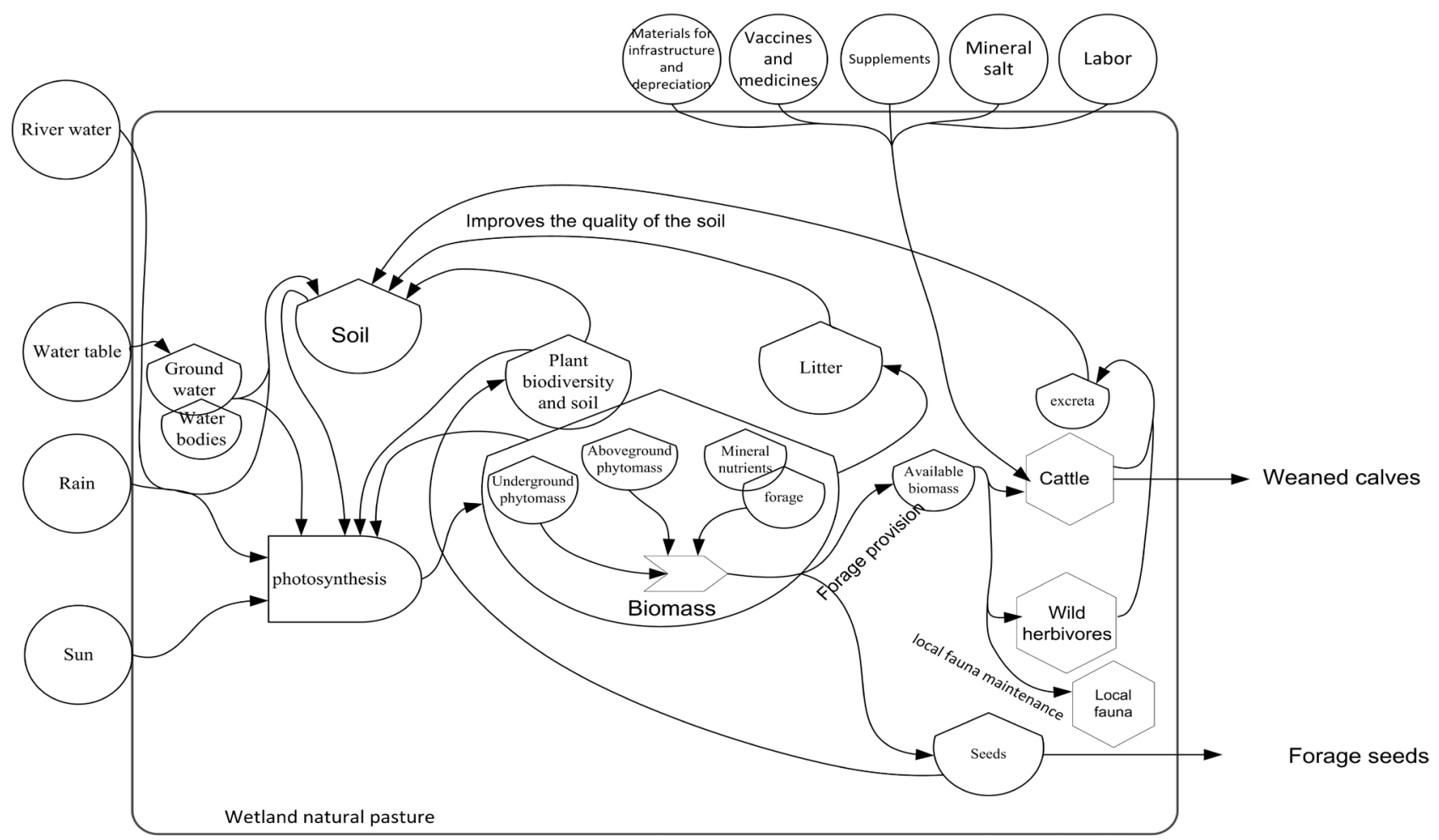

Figure 3. Emergy flow diagram showing the ecosystem services produced within a native pasture wetland. 
the gross domestic product (GDP) of the year. From this relation, it was possible to convert and evaluate each flow in the emergy of the system in monetary unit, the emdolar (em\$), which can be used to estimate, in emergy, the value spent on the support of human activity [12]. Forage provision for calves production was estimated as $22 \%$ of the grazing capacity ( $\mathrm{AU} \mathrm{ha} \mathrm{ha}^{-1}$ year). Emergy based indexes [12] and the emergy sustainability index (ESI) [31] were calculated (Table 1).

\subsection{Sustainability Efficiency}

Data envelopment analysis (DEA), a method for evaluating the productive efficiency of decision making units (DMUs) by optimising the weighed output/input ratio [32] was used so as to study the efficiency of sustainability of pasture ecosystems [33]. Each pasture ecosystem was considered a DMU. The inputs were Tr, ELR and EIR and the outputs include ESI, EYR and product (Table 1). Two DEA models: Constant Returns to Scale (CRS) and Variable Returns to Scale (VRS) [34] were tested with an output orientation.

\section{Results}

Forage genetic resources, productive traits and grazing capacity were variable in function of the conservation status of the native pasture wetland. Exotic pasture wetland exhibited lower plant richness (Table 2).

Table 1. Expressions and descriptions of emergetic indexes.

\begin{tabular}{|c|c|c|}
\hline Name of index & Expression & Description \\
\hline Renewable ratio $(\mathrm{R})$ & - & $\begin{array}{l}\text { Local/free renewable resource. } \mathrm{R} \text { is a renewability factor indicating the percentage of } \\
\text { renewable emergy locally available used by the system }\end{array}$ \\
\hline Nonrenewable sources $(\mathrm{N})$ & - & Local/free non-renewable resource \\
\hline Economy feedback (F) & - & Feedback from the economy or purchased resources \\
\hline Energy yield (E) & - & Energy yield of each product \\
\hline Total emergy output (Y) & $\mathrm{Y}=\mathrm{R}+\mathrm{N}+\mathrm{F}$ & Total emergy \\
\hline $\begin{array}{l}\text { Transformity or energy } \\
\text { transformation }(\mathrm{Tr})\end{array}$ & $\operatorname{Tr}=(\mathrm{R}+\mathrm{N})+\mathrm{F} / \mathrm{E}$ & $\begin{array}{l}\text { Emergy input per unit of available energy output (Emjoule/joule). Tr is the inverse } \\
\text { value of the system efficiency. }\end{array}$ \\
\hline Materials (M) & $M=M r+M n$ & $\begin{array}{l}\text { It includes the sum of renewable materials and energy }(\mathrm{Mr}) \text { and nonrenewable } \\
\text { materials and energy }(\mathrm{Mn}) \text {. }\end{array}$ \\
\hline Services (S) & $S=S r+S n+S s$ & $\begin{array}{l}\text { It includes the sum of renewable services (Sr), nonrenewable services (Sn) and } \\
\text { externalities (Ss) }\end{array}$ \\
\hline Emergy yield ratio (EYR) & $\mathrm{EYR}=\mathrm{Y} / \mathrm{F}$ & $\begin{array}{l}\text { Total emergy }(\mathrm{Y}) \text { divided by the sum of the feedback emergy of non-renewable inputs } \\
\text { from economy }(\mathrm{M}+\mathrm{S})\end{array}$ \\
\hline Emergy investiment ratio (EIR) & $\mathrm{EIR}=\mathrm{F} /(\mathrm{N}+\mathrm{R})$ & $\begin{array}{l}\text { It is the relation between flows of imported emergy (F) from the economy divided by } \\
\text { the local inputs from the environment }\end{array}$ \\
\hline $\begin{array}{l}\text { Environmental loading ratio } \\
\text { (ELR) }\end{array}$ & $E L R=(N+F) / R$ & $\begin{array}{l}\text { Ratio of total nonrenewable emergy }(\mathrm{N}+\mathrm{F}) \text { divided by the total renewable emergy }(\mathrm{R}) \\
\text { for a given productive process }\end{array}$ \\
\hline Emergy sustainable index (ESI) & $\mathrm{ESI}=\mathrm{EYR} / \mathrm{ELR}$ & $\begin{array}{l}\text { Ratio of EYR divided by ELR. ESI reflects the capacity of the grassland to provide } \\
\text { services with a minimum environmental pressure and a maximum economic profit }\end{array}$ \\
\hline Emergy exchange ratio (EER) & $\mathrm{EER}=\mathrm{Y} /[(\$) \times($ sej $/ \$)]$ & Ratio of emergy of the product and emergy received in a trade or purchase \\
\hline
\end{tabular}


Table 2. Summary of the forage genetic resources, plant richness and productive traits of native pasture wetland under three conservation status and exotic pasture wetland in optimum conservation status.

\begin{tabular}{|c|c|c|c|c|}
\hline & \multicolumn{3}{|l|}{ Conservation status } & \multirow{2}{*}{$\begin{array}{l}\text { Exotic/optimum } \\
\text { status }\end{array}$} \\
\hline & Optimum & Regular & Marginal & \\
\hline Forage genetic resources & $\begin{array}{l}\text { Predominance of } \mathrm{C} 3 \text { grasses } \\
\text { (Hymenachne amplexicaulis, } \\
\text { Luziola subintegra and } \\
\text { Steinchisma laxum) }\end{array}$ & $\begin{array}{l}\text { Predominance of C3 grasses ( } H \text {. } \\
\text { amplexicaulis and L. subintegra } \\
\text { and C4 (Reimarochloa spp. and } \\
\text { Cynodon dactylon) }\end{array}$ & $\begin{array}{l}\text { Predominance of } \mathrm{C} 4 \text { grasses } \\
\text { (Reimarochloa spp. and } \\
\text { Cynodon dactylon) and } \mathrm{C} 3 \text { ( } S \text {. } \\
\text { laxum and } H . \text { amplexicaulis) }\end{array}$ & $\begin{array}{l}\text { Predominance } \\
\text { of Urochloa } \\
\text { humidicola }\end{array}$ \\
\hline Plant richness & 15 & 15 & 13 & 4 \\
\hline $\mathrm{NPP}^{1}\left(\mathrm{t} \mathrm{DM} \mathrm{ha}^{-1}\right.$ year $\left.^{-1}\right)$ & 15.85 & 12.88 & 9.45 & 17.08 \\
\hline $\begin{array}{l}\text { Above forage biomass ( } \mathrm{t} \\
\mathrm{DM} \mathrm{ha}^{-1} \mathrm{year}^{-1} \text { ) }\end{array}$ & 10.22 & 7.80 & 6.41 & 8.93 \\
\hline Utilization threshold (\%) & 50 & 50 & 50 & 50 \\
\hline $\begin{array}{l}\text { Available forage } \\
\left(\mathrm{t} \mathrm{DM} \mathrm{ha}^{-1} \text { year }^{-1}\right)\end{array}$ & 5.11 & 3.90 & 3.21 & 4.46 \\
\hline $\begin{array}{l}\text { Grazing capacity } \\
(\mathrm{AU})^{2}\end{array}$ & $1.6(11.6$ or 8.7$)$ & $1.2(8.9$ or 6.7$)$ & $1.0(7.3$ or 5.5$)$ & $1.4(10.6$ or 7.6$)$ \\
\hline
\end{tabular}

${ }^{1} \mathrm{NNP}$ - Net primary productivity; ${ }^{2}$ One animal unit (cow of $350 \mathrm{~kg}$ with calf at the foot - about $450 \mathrm{~kg}$ ) was considered - Intake will be $450 \times 0.2(2 \%$ of live weight $)=9 \mathrm{~kg}$ of dry matter $(\mathrm{DM})$ per day $=3285 \mathrm{~kg} \mathrm{DM} / \mathrm{year}$. In parentheses there are estimated values of the grazing capacity for deer $(\mathrm{AU}=30 \mathrm{~kg})$ or capybara ( $\mathrm{AU}=40 \mathrm{~kg}$ ), respectively considering intake of $4 \%$ of the live weight.

Figure 3 shows the emergy system diagram of natural and exotic native pasture wetland ecosystem. The emergy of renewable input flows: sun, rain, river water, water table, support and contribution to the natural functioning of ecosystems, were also taken into consideration. The good services (export market) provided by wetland grasslands evaluated in this study included calves production. The values of R, EYR, ESI, EER and Tr found for the optimum status of the native pasture wetland were lower than the regular and the marginal status while ELR and EIR were higher than the regular and the marginal status (Table 3). Exotic pastures wetland presented higher values for Y, EIR, ELR in comparison to natural pastures. Natural pastures showed higher R (with values close to $90 \%$ ), regardless of their conservation status. Marginal status natural pastures presented higher $\operatorname{Tr}$ while optimum natural pastures presented lower Tr. All wetland natural pastures evaluated had higher EYR than exotic pastures, which indicates a greater use of secondary raw material. EIR values were very low for all the pasture ecosystems evaluated. ELR values obtained in this study were very low for all the ecosystems. Natural grasslands in an optimum state had EER values closer to 1 .

The monetary value of indirect provisioning services as forage production for calves' production was variable in function of the conservation status of the wet grasslands (Table 3 ).

Table 4 shows the processed data of the inputs and outputs of DEA and the efficiency from CRS and VRS models. All native pastures, regardless of their conservation status, were considered efficient when compared to the exotic pastures. 
Table 3. Emergy-based indexes and emdollar values for ecosystem services of native pastures wetland for calves production under different conservation status (CS), compared to planted exotic pasture of Urochloa humidicola under optimum conservation status.

\begin{tabular}{|c|c|c|c|c|}
\hline \multirow{2}{*}{ Emergy indexes } & \multicolumn{3}{|c|}{ Native pastures Wetland } & \multirow{2}{*}{$\begin{array}{l}\text { Exotic pasture } \\
\text { wetland }\end{array}$} \\
\hline & Marginal SC & Moderate SC & Optimum SC & \\
\hline $\mathrm{Y}\left(\mathrm{seJ} \cdot \mathrm{ha}^{-1}\right.$ year $)$ & $2.22 \mathrm{E}+15$ & $2.24 \mathrm{E}+15$ & $2.27 \mathrm{E}+15$ & $2.84 \mathrm{E}+15$ \\
\hline $\mathrm{R}(\%)$ & 92.09 & 91.39 & 90.16 & 72.17 \\
\hline $\operatorname{Tr}\left(\right.$ seJ.ha $\left.a^{-1}\right)$ & $3.60 \mathrm{E}+13$ & $3.0 \mathrm{E}+13$ & $2.32 \mathrm{E}+13$ & $2.89 \mathrm{E}+13$ \\
\hline EYR & 11.22 & 10.31 & 8.99 & 3.46 \\
\hline EIR & 0.10 & 0.11 & 0.13 & 0.41 \\
\hline ELR & 0.09 & 0.09 & 0.11 & 0.39 \\
\hline EER & 1.66 & 1.38 & 1.07 & 1.33 \\
\hline ESI & 130.57 & 109.47 & 82.39 & 8.97 \\
\hline Total sale (USD $\cdot \mathrm{ha}^{-1}$ year) & 113.37 & 137.52 & 170.05 & 180.27 \\
\hline $\begin{array}{l}\text { Forage provision for calves } \\
\text { production }\left(\mathrm{EM} \$ \cdot \mathrm{ha}^{-1} \text { year }\right)\end{array}$ & 13.77 & 13.89 & 14.11 & 17.65 \\
\hline
\end{tabular}

$\mathrm{Y}=$ Total emergy output; $\mathrm{R}=$ Renewable ratio; $\mathrm{Tr}$ = transformity; EYR = Emergy yield ratio; EIR = Emergy investiment ratio; ELR = Environmental loading ratio; EER = Emergy exchange ratio; ESI = Emergy sustainable index.

Table 4. Normalized data of inputs and outputs and DEA efficiency from CRS and VRS models for DMU's

\begin{tabular}{|c|c|c|c|c|c|c|c|}
\hline \multirow{2}{*}{ DMU's } & \multicolumn{3}{|c|}{ Input } & \multicolumn{2}{|c|}{ Output } & \multirow{2}{*}{ CRS } & \multirow{2}{*}{ VRS } \\
\hline & $\operatorname{Tr}$ & ELR & EIR & ESI & EYR & & \\
\hline Marginal NPW & 1.000 & 0.231 & 0.244 & 1.000 & 1.000 & 1.000 & 1.000 \\
\hline Moderate NPW & 0.833 & 0.231 & 0.268 & 0.838 & 0.919 & 1.000 & 1.000 \\
\hline Optimum NPW & 0.644 & 0.282 & 0.317 & 0.631 & 0.801 & 1.000 & 1.000 \\
\hline Optimum EPW & 0.802 & 1.000 & 1.000 & 0.068 & 0.308 & 0.309 & 0.309 \\
\hline
\end{tabular}

DEA = Data envelopment analysis; CRS = Constant Returns to Scale; VRS = Variable Returns to Scale; DMU's = decision making units (pasture ecosystem); native pasture wetland (NPW); exotic pasture wetland $(\mathrm{EPW}) ; \mathrm{Tr}=$ transformity; ELR = Environmental loading ratio; EIR = Emergy investment ratio; ESI = Emergy sustainable index; EYR = Emergy yield ratio

\section{Discussion}

The ultimate purpose of any pasture ecosystem management is to provide forage to grazing animals (domestic and wild) using pasture forage. Mismanagement of the pasture such as overgrazing may exceed sustainable carrying capacity and reduce forage production and plant diversity as shown in pastures with different status of conservation (Table 2).

Management practice interventions on wetland pastures may have implications on the plant diversity that enhance provision of ecosystem services [35] [36]. A common practice to increase forage provision in the region has been the replacement of natural grasslands by exotic grass, mainly Urochloa humidicola, 
that decrease plant richness (Table 2). Meta-analysis and vote-counting methods has showed positive effects of plant diversity on provision ecosystem services ensuring its benefits to human well-being [36]. The results of this study showed that regarding richness, plant diversity had little variation among natural wet grasslands but caused changes in the proportion of $\mathrm{C} 3$ grasses and $\mathrm{C} 4$ grasses, indicating the necessity for further studies to considering not only effects of richness, but evenness and species or functional groups composition [36]. Besides, communities dominated by $\mathrm{C} 4$ grasses generally have higher rates of primary productivity than communities dominated by $\mathrm{C} 3$ grasses. However, according to present study, the natural wet grasslands with predominance of C3 species were more productive. Such fact may be due to the predominance of $\mathrm{C} 4$ short grasses such as Reimarochloa spp., an annual forage species and Cynodon dactylon, a pioneer forage species in the natural wet grassland evaluated. In turn, communities dominated by exotic $\mathrm{C} 4$ grasses were highly productive.

Emergy synthesis approach was used to evaluate the services provided by native wetland grasslands under three conservation status and compared to exotic pastures in an optimum state of conservation on wetland. Emergy value measures the contribution of different resources to the holistic system, including the goods that the society uses and have market value. These services are a "user-side" approach [13]. Ecosystem services that are functions and processes not directly used by the society but which are necessary for goods and services of direct use [37], such as wildlife maintenance/habitat, plant and forage resources diversity, soil quality and forage mass are also evaluated within the ecosystem. These services are considered as a "donor-side" [13]. Two possible main paths can be used to assess the values for the ecosystem services: natural driving forces and human society and economy [37].

Emergy analysis differentiates the inputs from renewable, non-renewable, and imported sources. From these inputs, emergetic indexes are calculated and provide valuable information for making decisions regarding sustainability. The indexes used in the emergy synthesis account for the all resources used, both ecological and economic, which is an advantage in relation to the traditional economic indices. This method also allows for estimating and comparing the emergy values of different system components [38] [39].

Cultivated pastures with exotic species have a relatively high dependency on external inputs and moderate usage of local non-renewable resources. Such pastures need to be implemented with technical criteria and adequate environmental norms so that there are no negative impacts on the environment [40]. Exotic pastures showed a renewability of $72.17 \%$, meaning that $27.83 \%$ of the inputs were related to non-renewable sources of emergy. Although also sustainable, their use in wetlands may affect plant richness and other ecosystem components.

Natural pastures with best management practices have the highest environmental sustainability and the lowest load on the environment [36]. Natural wetland pastures are more sustainable, because they have the possibility to be main- 
tained under economic stress [38] [41].

The transformity ( $\mathrm{Tr}$ ) for the optimum status of wetland pastures was less than the exotic pastures (optimum status) and wetland pastures (marginal and moderate status) indicating higher efficiency in production. $\mathrm{Tr}$ is the inverse value of the system efficiency. As the number is small work with the inverse. $\operatorname{Tr}$ is the ratio of emergy required in transformations to energy untransformed products or services in a system, as well as the indication of the hierarchical level of the system resources [42] which is defined as solar emergy per unit energy $\left(\right.$ sej. $\left.\mathrm{J}^{-1}\right)$. It is recommended that "high quality products should not be used for low quality purposes" [43]. A method was established for assessing the product's working principles using energy quality hierarchy and $\operatorname{Tr}$ contributing to establish ecological quality criteria [44].

The renewability $(R)$ of the native wetland pastures with optimum status was less than the marginal and the moderate status but the efficiency of this system was higher. The pasture productivity of the optimal system is higher, making a greater production of livestock possible. The higher production of livestock requires greater consumption of economy resources, but this incorporation was responsible for a small reduction in renewability when compared to regular and optimal systems, but as it has already been discussed, the optimal system was much more efficient.

The total emergy $(\mathrm{Y})$ used to drive a process can be considered a measure of self-organisation that occurs in the environment to enable a given process. EYR shows the contribution of natural capital in relation to purchased resources. In this study, all native wetland pastures evaluated had EYR $>5$ in contrast to exotic pastures (3.46), which indicates a greater use of secondary raw material. EYR is an emergy performance index. An EYR $>5$ indicates the use of primary energy resources, strong market competition and that the developed product has a high economic benefit [38] [45]. On the other hand, the ELR shows the use of environmental services and reflects its environmental impact [33]. The highest value for exotic pastures (0.39) was similar to the production system of the Pampas (0.37), in Argentina [40]. When the values are less than 2, they indicate low environmental impact. Furthermore, another factor that contributes to dissipate negative impacts is large areas [46]. Nevertheless, it is not recommended to analyse the indices in isolation.

EIR values obtained in this study were low when compared to the systems that are more intensive such as milk production farms, which usually have values between 3 and 5 [47]. Natural wetland pastures presented values next to 0.1. A lower value indicates a lower economic cost with higher benefits. However, the values obtained here for exotic pastures $(0.42)$ were close to those obtained in the grazing cattle system in the Pampas (0.37). A high investment ratio may become uneconomic [38].

EER describes if the system is being remunerated by the production [48], which is the amount of emergy that can be purchased by one dollar in a year 
[38]. The value of 1 represents that all emergy used in the product has a return from the money received. In this study, native pasture in optimum state (1.07) had values next to 1 but received less than the emergy spent. The other pastures also spent more emergy in products than in money received.

ESI values obtained in this study for natural wet grasslands were very high, similar to those found in the indigenous production (115.98) in Mexico [40] [49]. Exotic pastures presented lower values (8.97). The greater ESI does not always indicate the sustainability of the process, since at ESI $>10$ the process is considered to be underdeveloped [50] [51]. Very low values indicate the possibility of the system to have become inviable over time. In the systems studied here, native pastures wetland are a low input system. Ecosystem sustainability involves deriving more goods and services from the environment than the economy [14]. ESI alone does not reveal the true sustainability because it is determined by multiple social, economic and ecological factors.

DEA analysis showed that DMUs with natural pastures produced larger outputs with a smaller amount of inputs, which makes them more efficient. Although natural wet pastures are DEA efficient regardless of their state of conservation, optimum state native pastures were as productive as exotic pastures, making the conservation and sustainable management of these pastures of utmost importance.

Overall, it is necessary that decision makers recognise ecosystem goods and services provided by well maintained native pasture wetland, seeking to ensure future economic welfare and environmental integrity [37]. The development of public policies for the conservation of these ecosystems will contribute to the biodiversity and ecosystem services conservation and the development of sustainability of the Pantanal region. There have been several international debates involving governments, scientific community and other stakeholders on an Intergovernmental science-policy Platform on Biodiversity and Ecosystem Services in order to optimize the generation of user-friendly knowledge of those elements of biodiversity that are considered ecosystem services [4] [5] [6] [52] [53].

Marginal regions such as Pantanal need to have sustainable low input livestock systems developed and valued, because there are several abandonment large areas as well as many areas intensified without technical criteria. The integration of positive externalities of native pasture based livestock [54], especially conserved and optimized by restoration should be compensated for the services provided.

\section{Acknowledgements}

We thank CNPq (474323/2013-7), Fundect (091/2015 SIAFEM 024370) and Embrapa for the financial support and we also thank Edimir de Freitas for the administrative support to the project. We also thank Luiz Alberto Pellegrin for the map edition and Balbina Maria Soriano for providing climatological normal data. 


\section{Conflicts of Interest}

The authors declare no conflicts of interest regarding the publication of this paper.

\section{References}

[1] Sharma, N.K. (2015) From Natural to Human-Impacted Ecosystems: Rationale to Investigate the Impact of Urbanization on Cyanobacterial Diversity in Soils. Biodiversity and Conservation, 24, 1007-1015.

https://doi.org/10.1007/s10531-015-0897-5

[2] Clarkson, B.R., Ausseil, A.G. and Gerbeaux, P. (2013) Wetland Ecosystem Services. In: Dymond, J.R., Ed., Ecosystem Services in New Zealand-Conditions and Trends, Manaaki Whenua Press, Lincoln, New Zealand, 192-202.

[3] Zedler, J.B. (2003) Wetland at Your Service: Reducing Impacts of Agriculture at the Watershed Scale. Frontiers in Ecology and the Environment, 1, 65-72. https://doi.org/10.1890/1540-9295(2003)001[0065:WAYSRI]2.0.CO;2

[4] MA (Millennium Ecosystem Assessment) (2005) Ecosystems and Human Well-Being: Synthesis. Island Press, Washington DC.

[5] ten Brink, P., Russi, D., Farmer, A., Badura, T., Coates, D., Förster, J., Kumar, R. and Davidson, N. (2013) The Economics of Ecosystems and Biodiversity for Water and Wetlands. Executive Summary. http://www.teebweb.org

[6] La Notte, A., D’Amato, S., Mäkinen, H., Paracchini, M.L., Liquete, C., Egoh, B., Geneletti, D. and Crossman, N.D. (2017) Ecosystem Services Classification: A Systems Ecology Perspective of the Cascade Framework. Ecological Indicators, 74, 392-402. https://doi.org/10.1016/j.ecolind.2016.11.030

[7] Haines-Young, R.H. and Potschin, M.B. (2018) Common International Classification of Ecosystem Services (CICES) v.5.1 and Guidance on the Application of the Revised Structure. Fabis Consulting Ltd., Nottingham [In English]. https://cices.eu/content/uploads/sites/8/2018/01/Guidance-V51-01012018.pdf https://doi.org/10.3897/oneeco.3.e27108

[8] Larigauderie, A. and Mooney, H.A. (2010) The Intergovernmental Science-Policy Platform on Biodiversity and Ecosystem Services: Moving a Step Closer to an IPCC-Like Mechanism for Biodiversity. Current Opinion in Environmental Sustainability, 2, 9-14. https://doi.org/10.1016/j.cosust.2010.02.006

[9] De Groot, R.S., Alkemade, R., Braat, L., Hein, L. and Willemen, L. (2010) Challenges in Integrating the Concept of Ecosystem Services and Values in Landscape Planning, Management and Decision-Making. Ecological Complexity, 7, 260-272. https://doi.org/10.1016/j.ecocom.2009.10.006

[10] Kuenzer, C. and Vo Quoc, T. (2013) Assessing the Ecosystem Services Value of Can Gio Mangrove Biosphere Reserve: Combining Earth Observation and Household-Survey-Based Analysis. Applied Geography, 45, 167-184. https://doi.org/10.1016/j.apgeog.2013.08.012

[11] Boerema, A., Rebele, A.J., Bodi, M.B., Esler, K.J. and Meire, P. (2017) Are Ecosystem Services Adequately Quantified? Journal of Applied Ecology, 54, 358-370. https://doi.org/10.1111/1365-2664.12696

[12] Odum, H.T. (1996) Environmental Accounting: Emergy and Environmental Policy Making. John Wiley and Sons, New York, $370 \mathrm{p}$.

[13] Pulselli, F.M., Coscieme, L. and Bastianoni, S. (2011) Ecosystem Services as a Counterpart of Emergy Flows to Ecosystems. Ecological Modelling, 222, 2924-2928. https://doi.org/10.1016/j.ecolmodel.2011.04.022 
[14] Coscieme, L., Pulselli, F.M., Marchettini, N., Sutton, P.C., Anderson, S. and Sweeney, S. (2014) Emergy and Ecosystem Services: A National Biogeographical Assessment. Ecosystem Services, 7, 152-159. https://doi.org/10.1016/j.ecoser.2013.11.003

[15] Vigne, M. (2014) Environmental Assessment of Livestock Systems with the Emergy Methodology: Efficiency of Extensive Livestock Systems in Harsh Environments. Perspective, 25, 1-4. https://doi.org/10.19182/agritrop/00038

[16] Alho, C.J.R. (2008) Biodiversity of the Pantanal: Response to Seasonal Flooding Regime ant to Environmental Degradation. Brazilian Journal of Biology, 68, 957-966. https://doi.org/10.1590/S1519-69842008000500005

[17] Mayle, F.E. and Whitney, B.S. (2012) Long-Term Perspectives on Tropical Forest-Savanna Dynamics in lowland Bolivia from the Last Ice Age until the Present. In: Myster, R.M., Ed., Ecotones between Forest and Grassland, Springer, New York, 189-207. https://doi.org/10.1007/978-1-4614-3797-0_8

[18] Santos, S.A., Desbiez, A., Crispim, S.M.A., Comastri Filho, J.A., Abreu, U.G.P. and Rodela, L.G. (2011) Natural and Cultivated Pastures and Their Use by Cattle. In: Junk, W.J., Da Silva, C.J., Nunes da Cunha, C. and Wantzen, K.M., Eds., The Pantanal: 298 Managing Pantanal Rangelands for Optimizing Carbon Flow. Effects of Growing Season and Pasture Type on Dry Mass Accumulation Ecology, Biodiversity and Sustainable Management of a Large Neotropical Seasonal Wetland, Pensoft Publisher, Sofia, Bulgaria, 327-353.

[19] Hamilton, S.K. (2002) Hydrological Controls of Ecological Structure and Function in the Pantanal Wetland (Brazil). In: McClain, M., Ed., The Ecohydrology of South American Rivers and Wetlands, International Association of Hydrological Sciences, Manaus, 133-158.

[20] Cardoso, E.L., Santos, S.A., Urbanetz, C., Carvalho Filho, A., Naime, U.J., Silva, M.L.N. and Curi, N. (2016) Relação entre solos e unidades da paisagem no ecossistema Pantanal. Pesquisa Agropecuária Brasileira, 51, 1231-1240. https://doi.org/10.1590/s0100-204x2016000900023

[21] Santos, S.A., Cardoso, E.L., Crispim, S.M.A., Soriano, B.M., Garcia, J.B. and Berselli, C. (2015) Protocolo: Índice de Conservação e Produtividade das Pastagens (ICPP) para a Fazenda Pantaneira Sustentável (FPS). Embrapa Pantanal. Documento 130. Embrapa Pantanal, Corumbá.

[22] Moraes, A. (1991) Produtividade animal e dinâmica de uma pastagem de pangola (Digitaria decumbens Stent), azevém (Lolium multiflorum Lam.) e trevo branco (Trifolium repens L.), submetida a diferentes pressões de pastejo. Thesis, Universidade Federal do Rio Grande do Sul, Porto Alegre, 200.

[23] Silva, J.D. and Queiroz, A.C. (1991) Análises químicas: métodos químicos e biológicos. 3rd Edition, UFV, Viçosa, 235.

[24] Rao, I.M. (1998) Root Distribution and Production in Native and Introduced Pastures in the South American Savannas. In: Box Jr., J.E., Ed., Root Demographics and Their Efficiencies in Sustainable Agriculture, Grassland and Forest Ecosystems, Springer, Berlin, 19-41. https://doi.org/10.1007/978-94-011-5270-9_2

[25] Santos, S.A., Desbiez, A., Abreu, U.G.P. and Crispim, S.M.A. (2008) Guia para estimativa da taxa de lotação e pressão de pastejo em pastagens nativas do Pantanal. Embrapa Pantanal, Corumbá, MS, 26 p.

[26] Stuth, J.W. and Sheffield, W.J. (1986) Determining Carrying Capacity for Combinations of Livestock, White-Tailed Deer, and Exotic Ungulates. In: Proceedings of the 1986 International Ranchers Roundup, Texas Agricultural Extension Service.

[27] Santos, S.A., Desbiez, A.L.J., Baldiviezzo Perotto, H.L. and Pellegrin L.A. (2013) Uso 
de tecnologia de precisão na estimativa da capacidade de suporte em pastagens sob uso múltiplo no Pantanal. Embrapa Pantanal. Circular Técnica 107, Embrapa Pantanal, Corumbá, $6 \mathrm{p}$.

[28] Desbiez, A.L.J., Santos, S.A. and Bodmer, R.E. (2009) Wildlife Habitat Selection and Sustainable Resource Management in a Neotropical Wetland. International Journal of Biodiversity and Conservation, 1, 11-20.

[29] Evans, R.A. and Love, R.M. (1957) The Step-Point Method of Sampling: A Practical Tool in Range Research. Journal of Range Management, 10, 208-212. https://doi.org/10.2307/3894015

[30] Pott, A., Oliveira, A.K.M., Damasceno-Junior, G.A. and Silva, J.S.V. (2011) Plant Diversity of the Pantanal Wetland. Brazilian Journal of Biology, 71, 265-273. https://doi.org/10.1590/S1519-69842011000200005

[31] Brown, M.R. and Ulgiati, S. (1997) Emergy-Based Indices and Ratios to Evaluate Sustainability: Monitoring Economies and Technology toward Environmentally Sound Innovation. Ecological Engineering, 9, 51-69. https://doi.org/10.1016/S0925-8574(97)00033-5

[32] Charnes, A., Cooper, W.W. and Rhodes, E. (1978) Measuring the Efficiency of Decision Making Units. European Journal of Operational Research, 2, 429-444. https://doi.org/10.1016/0377-2217(78)90138-8

[33] Ren, J., Manzardo, A., Mazzi, A., Fedele, A. and Scipioni, A. (2013) Emergy Analysis and Sustainability Efficiency Analysis of Different Crop-Based Biodiesel in Life Cycle Perspective. The Scientific World Journal, 2013, Article ID: 918514. https://doi.org/10.1155/2013/918514

[34] Coelli, T.J., Rao, D.S.P., O’Donnell, C.J. and Battese, G.E. (2005) An Introduction to Efficiency and Productivity Analysis. 2nd Edition, Springer, New York, 174.

[35] Wu, J., Zhao, Y., Yu, C., Luo, L. and Pan, Y. (2017) Land Management Influences Trade-Offs and the Total Supply of Ecosystem Services in Alpine Grassland in Tibet, China. Journal of Environmental Management, 193, 70-78. https://doi.org/10.1016/j.jenvman.2017.02.008

[36] Quijas, S., Schmid, B. and Balvanera, P. (2010) Plant Diversity Enhances Provision of Ecosystem Services: A New Synthesis. Basic and Applied Ecology, 11, 582-593. https://doi.org/10.1016/j.baae.2010.06.009

[37] Grönlund, E., Fröling, M. and Carlman, F. (2015) Donor Values in Emergy Assessment of Ecosystem Services. Ecological Modelling, 306, 101-105. https://doi.org/10.1016/j.ecolmodel.2014.10.011

[38] Londoño, A., Gallego, S.D. and Velásquez, H.I. (2014) Emergy Evaluation: A Tool for the Assessment of Sustainability in Project Development Natalia. Journal of Engineering Research and Applications, 4, 172-178.

[39] Lei, K., Zhou, S. and Wang, Z. (2014) Emergy Synthesis and Ecological Energy Accounting. In: Lei, K., Zhou, S. and Wang, Z., Eds., Ecological Energy Accounting for a Limited System: General Principles and a Case Study of Macao, Springer, Berlin, 1-21. https://doi.org/10.1007/978-3-642-45170-6_1

[40] Rótolo, G.C., Rydberg, T., Lieblein, G. and Francis, C. (2007) Emergy Evaluation of Grazing Cattle in Argentina's Pampas Agriculture. Agriculture Ecosystems \& Environment, 119, 383-395. https://doi.org/10.1016/j.agee.2006.08.011

[41] Cohen, M.J., Brown, M.T. and Shepherd, K.D. (2006) Estimating the Environmental Costs of Soil Erosion at Multiple Scales in Kenya Using Emergy Synthesis. Agriculture, Ecosystems \& Environment, 114, 229-269.

https://doi.org/10.1016/j.agee.2005.10.021 
[42] Brown, M.T., Odum, H.T. and Jorgensen, S.E. (2004) Energy Hierarchy and Transformity in the Universe. Ecological Modelling, 178, 17-28. https://doi.org/10.1016/j.ecolmodel.2003.12.002

[43] Odum, H.T. and Odum, B. (2003) Concepts and Methods of Ecological Engineering. Ecological Engineering, 20, 339-361. https://doi.org/10.1016/j.ecoleng.2003.08.008

[44] Midžić, I., Štorga, M. and Marjanović, D. (2014) Energy Quality Hierarchy and "Transformity" in Evaluation of Product's Working Principles. In: Lien, T.K., Ed., Procedia CIRP: 21 st CIRP Conference on Life Cycle Engineering, Elsevier B.V., Trondheim, Norway, 300-305. https://doi.org/10.1016/j.procir.2014.06.084

[45] Zhang, X.C., Ma, C., Zhan, S.F. and Chen, W.P. (2012) Evaluation and Simulation for Ecological Risk Based on Emergy Analysis and Pressure-State-Response Model in a Coastal City, China. Procedia Environmental Sciences, 13, 221-231. https://doi.org/10.1016/j.proenv.2012.01.021

[46] Barrella, B.A., Almeida, C.M.B. and Giannetti, B.F. (2005) Ferramenta para tomada de decisão considerando a interação dos sistemas de produção e o meio ambiente. Revista Produção, 15, 87-101. https://doi.org/10.1590/S0103-65132005000100008

[47] Eurich, J., Weirich Neto, P.H. and Rocha, C.H. (2013) Índices emergéticos de sustentabilidade da produção leiteira em uma propriedade de base familiar em Palmeira, Paraná, Brasil. Revista Ceres, 60, 332-338. https://doi.org/10.1590/S0034-737X2013000300005

[48] Agostinho, F., Diniz, G., Siche, R. and Ortega, E. (2008) The Use of Emergy Assessment and the Geographical Information System to Diagnostic Small Family Farms in Brazil. Ecological Modeling, 210, 37-57. https://doi.org/10.1016/j.ecolmodel.2007.07.007

[49] Martin, J.F., Diemont, S.A.W., Powell, E., Stantaon, M. and Levy-Tacher, S. (2006) Emergy Evaluation of the Performance and Sustainability of Three Agricultural Systems with Different Scales and Management. Agriculture, Ecosystems \& Environment, 115, 128-140. https://doi.org/10.1016/j.agee.2005.12.016

[50] Cao, K. and Feng, X. (2007) The Emergy Analysis of Multi-Product Systems. Process Safety and Environmental Protection, 85, 494-500.

https://doi.org/10.1205/psep07007

[51] Zhang, X.H., Wei, Y. and Li, M. (2014) Emergy Evaluation of an Integrated Livestock Wastewater Treatment System. Resources, Conservation and Recycling, 92, 95-107. https://doi.org/10.1016/j.resconrec.2014.09.003

[52] Larigauderie, A. and Mooney, H.A. (2010) The Intergovernmental Science-Policy Platform on Biodiversity and Ecosystem Services: Moving a Step Closer to an IPCC-Like Mechanism for Biodiversity. Current Opinion in Environmental Sustainability, 2, 9-14. https://doi.org/10.1016/j.cosust.2010.02.006

[53] Turnhout, E. and Neves, K. (2014) “Measurementality” in Biodiversity Governance: Knowledge, Transparency, and the Intergovernmental Science-Policy Platform on Biodiversity and Ecosystem Services (IPBES). Environment and Planning A, 46, 581-597. https://doi.org/10.1068/a4629

[54] Bernués, A., Ruiz, R., Olaizola, A., Villalba, D. and Casasús, I. (2011) Sustainability of Pasture-Based Livestock Systems in the European Mediterranean Context: Synergies and Trade-Offs. Livestock Science, 139, 44-57. https://doi.org/10.1016/j.livsci.2011.03.018 


\section{Appendix 1. Emergy Contability of Wetland Pasture of the Pantanal with Optimum Conservation Status}

\begin{tabular}{|c|c|c|c|c|c|c|c|c|c|c|}
\hline Category & Item & $\begin{array}{c}\text { Renewability } \\
\text { fraction }\end{array}$ & Quantity & Units & Factor & Transformity & $\begin{array}{c}\text { Renewable } \\
\text { emergy } \\
\text { flow }\end{array}$ & $\begin{array}{l}\text { Non-renewable } \\
\text { emergy flow }\end{array}$ & $\begin{array}{c}\text { Total } \\
\text { emergy } \\
\text { flow }\end{array}$ & $\%$ \\
\hline $\mathrm{R} 1$ & Sun & 1 & 5.29 & $\mathrm{kWh} / \mathrm{m}^{2} /$ year & $3.60 \mathrm{E}+10$ & 1 & $1.90 \mathrm{E}+11$ & $0.00 \mathrm{E}+00$ & $1.90 \mathrm{E}+11$ & 0.01 \\
\hline $\mathrm{R} 2$ & Rain & 1 & 1.30 & $\mathrm{~m}^{3} / \mathrm{m}^{2} /$ year & $5.00 \mathrm{E}+10$ & 31,000 & $2.02 \mathrm{E}+15$ & $0.00 \mathrm{E}+00$ & $2.02 \mathrm{E}+15$ & 88.71 \\
\hline R3 & Water table & 1 & 3.65 & $\mathrm{~m}^{3} / \mathrm{m}^{2} /$ year & $5.00 \mathrm{E}+06$ & 18,4800 & $3.37 \mathrm{E}+12$ & $0.00 \mathrm{E}+00$ & $3.37 \mathrm{E}+12$ & 0.15 \\
\hline M1 & $\begin{array}{l}\text { Vaccines and } \\
\text { medicines }\end{array}$ & 0 & 0.04 & $\mathrm{Kg} / \mathrm{ha} /$ year & 1 & $1.48 \mathrm{E}+13$ & $0.00 \mathrm{E}+00$ & $5.77 \mathrm{E}+11$ & $5.77 \mathrm{E}+11$ & 0.03 \\
\hline M2 & Calcium carbonate & 0 & 25.25 & $\mathrm{Kg} / \mathrm{ha} /$ year & 1 & $1.00 \mathrm{E}+12$ & $0.00 \mathrm{E}+00$ & $2.53 \mathrm{E}+13$ & $2.53 \mathrm{E}+13$ & 1.11 \\
\hline M3 & Magnesium oxide & 0 & 6.42 & $\mathrm{Kg} / \mathrm{ha} /$ year & 1 & $3.80 \mathrm{E}+11$ & $0.00 \mathrm{E}+00$ & $2.44 \mathrm{E}+12$ & $2.44 \mathrm{E}+12$ & 0.11 \\
\hline M5 & $\mathrm{NaCl}$ & 0.2 & 64.50 & $\mathrm{Kg} / \mathrm{ha} /$ year & 1 & $1.68 \mathrm{E}+12$ & $2.17 \mathrm{E}+13$ & $1.08 \mathrm{E}+14$ & $1.08 \mathrm{E}+14$ & 4.77 \\
\hline M6 & Others materials & 0 & 6.63 & US\$/ha/year & 1 & $1.18 \mathrm{E}+13$ & $0.00 \mathrm{E}+00$ & $7.82 \mathrm{E}+13$ & $7.82 \mathrm{E}+13$ & 3.44 \\
\hline S1 & Depreciation & 0 & 1.92 & US\$/ha/year & 1 & $1.18 \mathrm{E}+13$ & $0.00 \mathrm{E}+00$ & $2.26 \mathrm{E}+13$ & $2.26 \mathrm{E}+13$ & 1.00 \\
\hline S2 & Labor & 0.5 & 1.29 & US\$/ha/year & 1 & $1.18 \mathrm{E}+13$ & $7.61 \mathrm{E}+12$ & $7.61 \mathrm{E}+12$ & $1.52 \mathrm{E}+13$ & 0.67 \\
\hline
\end{tabular}

